\title{
Rust Resistance in Arabic Coffee Cultivars in Northern Paraná
}

\author{
Leandro Del Grossi ${ }^{1}$, Tumoru Sera ${ }^{1}$, Gustavo Hiroshi Sera ${ }^{1 *}$, Inês Cristina de Batista \\ Fonseca $^{2}$, Dhalton Shiguer Ito ${ }^{1}$, Luciana Harumi Shigueoka ${ }^{1,2}$, Elder Andreazi ${ }^{1,2}$ and Filipe \\ Gimenez Carvalho ${ }^{1}$ \\ ${ }^{1}$ Área de Melhoramento e Genética Vegetal; Instituto Agronômico do Paraná; C. P.: 481; 86001-970; Londrina - \\ PR - Brasil; ${ }^{2}$ Centro de Ciências Agrárias; Universidade Estadual de Londrina; 86051-980; Londrina - PR - Brasil
}

\begin{abstract}
The objective of the study was to evaluate the resistance to rust in coffee cultivars developed by research institutes of Brazil in Paraná state. Resistance to the local leaf rust races was assessed in high disease intensity field conditions at Londrina and Congonhinhas in 2009 and 2010. The cultivars were developed by the EPAMIG/UFV, IAPAR, IAC and MAPA/Procafé. The resistant standard 'IAPAR 59' and the susceptible standards Catuaí Vermelho IAC 144' and 'Bourbon Amarelo' were used. A randomized block design with three replications and plots with 10 plants was used. A scale from 1 to 5 based on the rust intensity was used to evaluate the resistance. The Catiguá MG 1, Catiguá MG 2, IAPAR 59, IPR 98, IPR 104, Palma II, Paraíso H-419-10-6-2-5-1, Paraíso H-41910-6-2-10-1, Paraíso H-419-10-6-2-12-1, Pau Brasil MG 1 and Sacramento MG 1 cultivars presented complete resistance to rust at Londrina and Congonhinhas. The cultivars derived from the Catucai germplasm were susceptible or showed different levels of partial resistance. Partial resistance to the rust was observed in several coffees derived from "Hibrido de Timor". 'Acaũ̃' and 'Obatã IAC 1669-20' presented complete resistance at Londrina, but at Congonhinhas, they were partially resistant, indicating that different rust races have occurred at these two locations.
\end{abstract}

Key words: Breeding, Coffea, Hemileia vastatrix, Híbrido de Timor, SH genes

\section{INTRODUCTION}

Coffee leaf rust, caused by the Hemileia vastatrix Berk. et Br. fungus, is considered as the main disease in this crop. The disease can be efficiently controlled with chemical and genetic control (Zambolim et al. 1999).

In spite of the efficiency of the fungicides, the development and use of resistant cultivars is economically the best alternative to control the disease (Waller et al. 2007). However, obtaining the resistant cultivars has been a constant challenge for the breeders because over the time, the plants can become susceptible to new races of the pathogen (Várzea and Marques 2005), thus making the control of the disease difficult by the use of these cultivars (Zambolim et al. 2005).

To date, nine major resistance genes have been identified in coffee plants of different genotypes, characterized by the sign $S H$. These resistance genes were found mainly in $\mathrm{C}$. arabica $(\mathrm{SH} 1, \mathrm{SH} 2$, SH4, SH5), C. canephora (SH6, SH7, SH8, SH9) and $\mathrm{C}$. liberica (SH3). The SH6, SH7, SH8, and SH9 genes were also found in Hibrido de Timor derivatives and Icatu, both interspecific hybrids between $C$. arabica and $C$. canephora

*Author for correspondence: gustavosera@iapar.br 
(Bettencourt and Noronha-Wagner 1971, Bettencourt and Rodrigues Júnior 1988, NoronhaWagner and Bettencourt 1967, Rodrigues-Júnior et al. 1975). The existence of other resistance genes in "Hibrido de Timor" derivatives and "Icatu" has been confirmed because the resistance was maintained to new rust races that defeated $S H 5$, SH6, SH7, SH8 and SH9 genes (Rodrigues-Júnior et al. 2000).

The break in the resistance by the new rust races in many cultivars before considered resistant, such as the "Catimor" germplasm, has occurred in various regions of the world. The existing physiological rust races have already broken almost all the $S H$ resistance genes (Várzea et al. 2002). Currently, more than 45 physiological rust races have been characterized in the world as the carriers of the nine virulence genes ( $v 1$ to $v 9$ ), alone or in combination. Some races have a wide virulence spectrum such as the XXXIX race, with seven virulence genes, isolated from the samples from India (Várzea and Marques 2005).

Genetic breeding for rust resistance has been carried out by several research institutes in Brazil using as resistant sources coffee trees, including the "Sarchimor", "Catimor", "Catindu", "Icatu" and "Catucaí" germplasm. Many cultivars of these germplasm presented complete resistance to rust but currently have different resistance levels or have shown susceptibility due to the appearance of new races.

The objective of the present study was to assess the resistance to rust in the coffee cultivars developed by the research institutes in Brazil at two locations in Northern Paraná.

\section{MATERIALS AND METHODS}

The experiments were set up in the field in the municipalities of Londrina and Congonhinhas in the Paraná (Brazil). In Londrina, the experiment was set up at Experimental Station of the Paraná Agronomic Institute $\left(23^{\circ} 22^{\prime} \mathrm{S}, 51^{\circ} 10^{\prime \prime} \mathrm{W}\right)$ in red distroferric latosol type soil at $585 \mathrm{~m}$ altitude, with $20.8{ }^{\circ} \mathrm{C}$ mean annual temperature. In
Congonhinhas, the experiment was set up at Experimental Farm Serinha II (23 $30^{\prime}$ S, 50 10" W) in red distroferric latosol type soil at $750 \mathrm{~m}$ altitude, with $19.5^{\circ} \mathrm{C}$ mean annual temperature.

The cultivars assessed were developed by the Empresa de Pesquisa Agropecuária de Minas Gerais/ Universidade Federal de Viçosa (EPAMIG/UFV), Agricultural Research Institute of Paraná (IAPAR), Instituto Agronômico de Campinas (IAC) and MAPA/ PROCAFÉ (Table 1). 'IAPAR 59' was used as resistance standard and 'Catuaí Vermelho IAC144' and 'Bourbon Amarelo' were used as susceptible cultivars.

The experiments were set up in October and November 2006, in Congonhinhas and Londrina, respectively, in the spacing $2.50 \times 0.75 \mathrm{~m}$, in a randomized block design with three replications and plots of 10 plants. In Congonhinhas, the resistance to rust was assessed only in 2010 while in Londrina, the assessments were made in 2009 and 2010.

The resistance assessments were for the local population of rust races present in Londrina and Congonhinhas under the conditions of high disease intensity in the field. In the experiment in Congonhinhas, an assessment was made in July 2010 (46 months after the planting). The assessments in Londrina were made in July 2009 (33 months after the planting) and July 2010 (46 months after the planting). A scale of scores was used to assess the rust intensity ranging from 1 to 5, where: score $1=$ plant without chlorotic lesions on the leaf; score 2 = number of lesions per leaf, on average, between 1 and 4, without sporulation; score $3=$ number of lesions with between 1 and 10 spores per leaf and with 1 to $10 \%$ leaves with sporulation; score $4=$ number of lesions with between 11 and 20 spores per leaf and with $11 \%$ to $35 \%$ of the leaves with sporulation; score $5=$ more than 20 lesions with spores per leaf at more than $35 \%$ leaves with sporulation. The lower third to the upper third of the coffee tree was assessed. The data was submitted to the analysis of variance and the means were compared by the Scott-Knott test at 5\% significance. The genes statistical program was used (Cruz 2001). 
Table 1 - Description of arabic coffee cultivars assessed in the experiments set up in the north of Parana state, Brazil, to assess resistance to rust.

\begin{tabular}{|c|c|c|}
\hline Cultivars & Description & Institute \\
\hline Araponga MG 1 & "Catuaî́" x "Híbrido de Timor" & Epamig/ UFV \\
\hline Catiguá MG 1 & "Catuaî" x "Híbrido de Timor" & Epamig/UFV \\
\hline Catiguá MG 2 & "Catuaî" x "Híbrido de Timor" & Epamig/ UFV \\
\hline Oeiras MG 6851 & "Catimor" & Epamig/ UFV \\
\hline Paraíso H-419-10-6-2-5-1 & "Catuaî" x "Híbrido de Timor" & Epamig/UFV \\
\hline Paraíso H-419-10-6-2-10-1 & "Catuaî" x "Híbrido de Timor" & Epamig/UFV \\
\hline Paraíso H-419-10-6-2-12-1 & "Catuaî" x "Híbrido de Timor" & Epamig/UFV \\
\hline H-419-3-3-7-16-4-1 & "Catuaî" x "Híbrido de Timor" & Epamig/ UFV \\
\hline Pau Brasil MG 1 & "Catuaî" x "Híbrido de Timor" & Epamig/UFV \\
\hline Sacramento MG 1 & "Catuaî" x "Híbrido de Timor" & Epamig/UFV \\
\hline Bourbon Amarelo & "Bourbon Vermelho" x "Amarelo de Botucatu" & IAC \\
\hline Catuaí Vermelho IAC 144 & "Mundo Novo" x "Caturra" & IAC \\
\hline Obatã IAC 1669-20 & "Sarchimor" x "Catuaî" & IAC \\
\hline Tupi IAC 1669-33 & "Sarchimor" & IAC \\
\hline IAPAR 59 & "Sarchimor" & IAPAR \\
\hline IPR 98 & "Sarchimor" & IAPAR \\
\hline IPR 99 & "Sarchimor" & IAPAR \\
\hline IPR 100 & "Catuaî" x ("Catuaî" x "series BA-10 coffee") & IAPAR \\
\hline IPR 103 & "Catuaî" x "Icatu" & IAPAR \\
\hline IPR 104 & "Sarchimor" & IAPAR \\
\hline Catucaí Amarelo 2 SL & "Icatu" x "Catuaî" & MAPA/Procafé \\
\hline Catucaí Vermelho 20/15 cv 476 & "Icatu” x "Catuaî" & MAPA/Procafé \\
\hline Catucaí Amarelo 20/15 cv 479 & "Icatu” x "Catuaî" & MAPA/Procafé \\
\hline Catucaí Amarelo 24/137 & "Icatu” x "Catuaî" & MAPA/Procafé \\
\hline Catucaí Vermelho 785/15 & "Icatu" x "Catuaî" & MAPA/Procafé \\
\hline Acauã & "Sarchimor" x "Mundo Novo" & MAPA/Procafé \\
\hline Palma II & “Catuaî” x “Catimor” & MAPA/Procafé \\
\hline Sabiá 398 & "Catimor" x "Acaiá" & MAPA/Procafé \\
\hline
\end{tabular}

\section{RESULTS AND DISCUSSION}

The mean rust intensity was high in the two locations, as could be observed in the susceptible standards 'Bourbon Amarelo' and 'Catuaí Vermelho IAC 144'. The highest susceptibility of 'Bourbon Amarelo' was observed at Congonhinhas, where it was statistically more susceptible than 'Catuai Vermelho IAC144' (Table 2).

Generally, the cultivars descended from the "Catucai" germplasm were susceptible or presented different levels of partial resistance (incomplete resistance). 'Catucaí Amarelo 24/137' was statistically equal to the susceptible standard in Londrina, but in Congonhinhas, the rust intensity was less than in the susceptible standards, indicating that there was still partial resistance to the rust races existing in this location. In Londrina, the rust intensity was less in the Catucaí Vermelho 20/15 cv 476, Catucaí Vermelho 785/15 and
Catucaí Amarelo 2SL cultivars than in the susceptible standard, but statistically equal to the IPR 100, considered susceptible in the state of Paraná by Sera et al. (2010b). 'Catucaí Vermelho 20/15 cv 476', 'Catucaí Amarelo 20/15 cv 479', 'Catucaí Vermelho 785/15' and 'IPR 100' were statistically equal to the susceptible standard 'Catuaí Vermelho IAC 144' in the municipality of Congonhinhas, while 'Catucaí Amarelo 2SL' presented incomplete resistance similar to that of 'IPR 103'. In Londrina, 'Catucaí Amarelo 20/15 cv 479' was partially resistant not different from the IPR 103 cultivar ("Catucaî") that had presented a good level of partial resistance in a previous study by Sera et al. (2010b). The resistance found in 'IPR 103' and 'Catucaí Amarelo 20/15 cv 479' probably came from "Icatu", because different partial resistance levels had been frequently detected in "Icatu" plants (Monaco and Carvalho 1975, Eskes and Carvalho 1983, Eskes and Costa 1983, Eskes et al. 1990). Inheritance studies in "Icatu" plants and "Hibrido de Timor" 
descendents with different levels of incomplete resistance indicated the presence of one or a few minor partially dominant genes. These genetic factors when in homozygosis condition or associated, confer almost complete resistance (Eskes et al. 1990). Other authors have also reported that 'Catucaí Amarelo 24/137', 'Catucaí Vermelho 20/15 cv 476', 'Catucaí Amarelo 20/15 cv 479', 'Catucaí Vermelho 785/15' and 'Catucaí
Amarelo 2SL' have partial resistance to rust (Matiello et al. 2010), but it was seem in the present study that in some locations these genotypes were as susceptible as 'Catuai Vermelho IAC144' and 'IPR 100', depending on the location. Matiello et al. (2005) reported that "Catucai" lines are attacked by rust at different levels, but several do not lose leaves sharply and chemical control is easy using copper fungicides.

Table 2 - Mean scores of rust intensity on coffee cultivars assessed under field conditions in the municipalities of Londrina (2009 and 2010) and Congonhinhas (2010).

\begin{tabular}{|c|c|c|}
\hline Cultivars ${ }^{(1)}$ & Londrina ${ }^{(2)}$ & Congonhinhas $^{(2)}$ \\
\hline Bourbon Amarelo & $3,200 \mathrm{a}$ & $5,000 \mathrm{a}$ \\
\hline Catucaí Amarelo 24/137 & $2,950 \mathrm{a}$ & $3,166 \mathrm{c}$ \\
\hline Catuaí Vermelho IAC 144 & $2,866 \mathrm{a}$ & $3,666 \mathrm{~b}$ \\
\hline Catucaí Vermelho 20/15 cv 476 & $2,616 \mathrm{~b}$ & $3,666 \mathrm{~b}$ \\
\hline Catucaí Vermelho 785/15 & $2,616 \mathrm{~b}$ & $3,833 \mathrm{~b}$ \\
\hline Catucaí Amarelo $2 \mathrm{SL}$ & $2,450 \mathrm{~b}$ & $2,666 \mathrm{c}$ \\
\hline H-419-3-3-7-16-4-1 & $2,366 \mathrm{~b}$ & $2,333 \mathrm{c}$ \\
\hline IPR 100 & $2,316 b$ & $3,333 \mathrm{~b}$ \\
\hline Oeiras MG 6851 & $1,950 \mathrm{~b}$ & $3,166 \mathrm{c}$ \\
\hline IPR 103 & $1,700 \mathrm{c}$ & $2,666 \mathrm{c}$ \\
\hline Catucaí Amarelo 20/15 cv 479 & $1,616 \mathrm{c}$ & $3,333 \mathrm{~b}$ \\
\hline Tupi IAC 1669-33 & $1,583 \mathrm{c}$ & $2,333 \mathrm{c}$ \\
\hline Sabiá 398 & $1,500 \mathrm{c}$ & $2,000 \mathrm{~d}$ \\
\hline Araponga MG 1 & $1,466 \mathrm{c}$ & $2,166 \mathrm{~d}$ \\
\hline IPR 99 & $1,233 \mathrm{~d}$ & $1,666 \mathrm{~d}$ \\
\hline Acauã & $1,200 \mathrm{~d}$ & $2,666 \mathrm{c}$ \\
\hline Catiguá MG 2 & $1,183 \mathrm{~d}$ & $1,000 \mathrm{e}$ \\
\hline IAPAR 59 & $1,150 \mathrm{~d}$ & $1,000 \mathrm{e}$ \\
\hline Pau Brasil MG 1 & $1,150 \mathrm{~d}$ & $1,333 \mathrm{e}$ \\
\hline IPR 104 & $1,133 \mathrm{~d}$ & $1,333 \mathrm{e}$ \\
\hline Obatã IAC 1669-20 & $1,100 \mathrm{~d}$ & $2,500 \mathrm{c}$ \\
\hline Palma II & $1,100 \mathrm{~d}$ & $1,000 \mathrm{e}$ \\
\hline IPR 98 & $1,083 \mathrm{~d}$ & $1,000 \mathrm{e}$ \\
\hline Paraíso H-419-10-6-2-12-1 & $1,083 \mathrm{~d}$ & $1,000 \mathrm{e}$ \\
\hline Sacramento MG 1 & $1,083 \mathrm{~d}$ & $1,333 \mathrm{e}$ \\
\hline Catiguá MG 1 & $1,016 \mathrm{~d}$ & $1,000 \mathrm{e}$ \\
\hline Paraíso H-419-10-6-2-5-1 & $1,000 \mathrm{~d}$ & $1,000 \mathrm{e}$ \\
\hline Paraíso H-419-10-6-2-10-1 & $1,000 \mathrm{~d}$ & $1,000 \mathrm{e}$ \\
\hline
\end{tabular}

${ }^{1}$ Cultivars ranked decreasingly according to rust intensity occurred in Londrina.

${ }^{2}$ Means followed by the same letters did not differ statistically by the Scott-Knott test at $5 \%$. Scale of scores at from 1 to 5 for rust assessment.

'IPR 100' was originated from a crossing between "Catuaî" and one hybrid ("Catuaî" x series BA-10 coffee) carrying Coffea liberica genes, but it was probably not a carrier of the $\mathrm{SH} 3$ gene, because in Londrina coffee trees with this gene were completely resistant to the rust (Sera et al. 2007a, 2010b). 'IPR 100' is resistant to race II (gene v5) of $H$. vastatrix, while the cultivars from the "Catuaî" germplasm, carriers only of SH5, are susceptible (Capucho et al. 2007). As 'IPR 100' was susceptible at Congonhinhas, statistically equal to the susceptible standard Catuai Vermelho IAC144, some resistance gene from 'IPR 100' was broken by some race, different from race II.

'Oeiras MG 6851' was statistically equal to 'IPR 103' at Congonhinhas, indicating that the resistance had not yet been completely broken in this cultivar from "Catimor". At Londrina, the resistance of this cultivar was completely broken, because it was statistically equal to 'IPR 100'. 
Pereira et al. (2010) reported that 'Oeiras MG 6851 ' presented predominantly vertical resistance reaction to the $H$. vastatrix races prevalent in the coffee regions of Minas Gerais and that the infected plants presented horizontal resistance. Other authors have also observed the occurrence of partial resistance in coffees derived from "Hibrido de Timor" with resistance broken in the "Colombia' ("Catimor") (Alvarado 2005) and 'IPR 108' ("Sarchimor" x "Catucaî") cultivars (Sera et al. 2010b).

This break in resistance in "Hibrido de Timor" derivatives observed in 'Oeiras MG 6851' also seemed to be occurring in 'Acauã' ("Sarchimor" $x$ "Mundo Novo"), 'Araponga MG 1' ("Catuaî́" $x$ "Hibrido de Timor"), 'H-419-3-3-7-16-4-1' ("Catuâ̂" x "Hibrido de Timor"), 'IPR 99' ("Sarchimor"), 'Obatã IAC 1669-20' ("Sarchimor" x "Catuaî"), 'Sabiá 398' ("Catimor" x "Acaiá") and 'Tupi IAC 1669-33' ("Sarchimor"). Costa et al. (2007) also identified "Catimor" progenies with complete resistance and others with partial resistance to the rust. These authors also reported that 'Catucaí Vermelho 36/6', 'Oeiras MG 6851' and 'Palma I' ("Catimor" x "Catuấ") presented quantitative resistance to race II of Hemileia vastatrix. Matiello et al. (2005) reported that 'Palma I', 'Palma II' and 'Sabiá 398' have already presented some plants attacked by rust, but with less intense of leaf-shedding.

Selection might be made on these cultivars with partially broken resistance to obtain the progenies with a higher frequency of the plants with complete resistance (scores 1 and 2). Sera et al. (2010a) identified the progenies of the IPR 99 and IPR 107 ('IAPAR 59' x 'Mundo Novo IAC 3764') cultivars with a higher percentage of the plants with complete resistance by the test crosses (progeny to be tested $\mathrm{x}$ susceptible genotypes). Using the same method, Sera et al. (2007b) selected the progenies from the IAPAR 59 and Tupi IAC 1669-33 cultivars with a higher number of resistance genes not broken by the local population of rust races.

'Acauã', 'Araponga MG 1', 'Obatã IAC 1669-20' and 'Tupi IAC 1669-33' have been normally mentioned as being resistant by various authors (Carvalho et al. 2008, Matiello et al. 2005, 2010), but in the present study it was observed that resistance had been broken in these cultivars. It was interesting to note that 'Acauã' and 'Obatã IAC 1669-20' were completely resistant in Londrina, statistically equal to the standard
IAPAR 59, but were only partially resistant at Congonhinhas, at the same level as 'IPR 100', indicating that at the latter location, there were rust races with more virulence genes. The same occurred for 'Catucaí Amarelo 20/15 cv 479' that was partially resistant at Londrina and susceptible at Congonhinhas.

However, it could be possible that this partial resistance was not durable as occurred in the Cauvery ("Catimor") cultivar where partial resistance was observed only at the start. In a short time, the susceptibility of these coffee trees and the aggressiveness of the rust increased and this cultivar was susceptible under field conditions in India (Várzea and Marques 2005). It could be probable that the partial resistance observed in these cultivars derived from "Hibrido de Timor" and "Catucai" was durable, depending on the races present at the location. In Paraná state 'IPR 103' has presented the same level of partial resistance for more than 12 years (Sera T. 2010, personal communication).

The cultivars that presented complete resistance at the two locations and in the two assessment years were: Catiguá MG 1, Catiguá MG 2, IAPAR 59, IPR 98, IPR 104, Palma II, Paraíso H-419-10-6-25-1, Paraíso H-419-10-6-2-10-1, Paraíso H-41910-6-2-12-1, Pau Brasil MG 1 and Sacramento MG 1. All these cultivars were "Hibrido de Timor" derivatives and confirmed the resistance reported by other authors (Carvalho et al. 2008, Matiello et al. 2010, Pereira et al. 2010, Sera et al. 2010b), except for 'Palma II' that had already presented some susceptible plants with less leaf shedding (Matiello et al. 2005). The "Hibrido de Timor" population has at least five dominant genes SH5, SH6, SH7, SH8, SH9 (Bettencourt et al. 1992), and SH6 to SH9 came from C. canephora (Bettencourt and Rodrigues-Júnior 1988). In addition to these already identified, it might be likely that other resistance genes could be present in "Hibrido de Timor" (Várzea and Marques 2005). Two monogenetic resistant factors, different from SH6 to $\mathrm{SH} 9$, were detected in Brazil; one in C. canephora cv. Kouillou and another in "Icatu" (Eskes 1989). In another study in Londrina, it was observed that the $\mathrm{SH} 1, \mathrm{SH} 2$, SH4, SH5 and SH8 genes had already been broken by the local population of rust races. Furthermore, it was observed that coffee tree carriers of $\mathrm{SH}$, Hibrido de Timor CIFC 832/1 and CIFC 832/2 had complete resistance (Sera et al. 2007a). It could be probable that these cultivars that presented 
complete resistance at two locations were the carriers of the $\mathrm{SH} 5, \mathrm{SH}$, $\mathrm{SH} 7, \mathrm{SH} 8$ and $\mathrm{SH} 9$ genes and other resistance genes to rust in different combinations.

\section{CONCLUSIONS}

The cultivars Catiguá MG 1, Catiguá MG 2, IAPAR 59, IPR 98, IPR 104, Palma II, Paraíso H419-10-6-2-5-1, Paraíso H-419-10-6-2-10-1, Paraíso H-419-10-6-2-12-1, Pau Brasil MG 1 and Sacramento MG 1 presented complete resistance to rust in Londrina and Congonhinhas.

The cultivars derived from the Catucaí germplasm were susceptible or showed different levels of partial resistance.

Partial resistance to the rust was observed in several "Hibrido de Timor" derivatives as in the case of the 'Tupi IAC 1669-33'.

'Acauã' and 'Obatã IAC 1669-20' presented complete resistance in Londrina but were only partially resistant in Congonhinhas, indicating that different rust races occurred at these two locations.

\section{ACKNOWLEDGEMENTS}

At the Universidade Estadual de Londrina (UEL), the coordination of the Post-graduate degree in Agronomy. CNPq (National Council for Scientific and Technological Development) for granting the scholarship. When the Brazilian Consortium for Coffee Research and Development (Consórcio Pesquisa Café)/ Embrapa Café for the financial support to projects developed at the Agricultural Research Institute of Parana (IAPAR).

\section{REFERENCES}

Alvarado GA. Evolution of Hemileia vastatrix virulence in Colômbia. In: Zambolim L, Zambolim EM, Várzea VMP, editors. Durable Resistance to Coffee Leaf Rust. Viçosa: UFV; 2005. p. 99-116.

Bettencourt AJ, Lopes J, Palma S. Factores genéticos que condicionam a resistência às raças de Hemileia vastatrix Berk. et Br. dos clones-tipo dos grupos 1, 2 e 3 de derivados de Híbrido de Timor. Brotéria Genética. 1992; 13: 185-194.

Bettencourt AJ, Noronha-Wagner M. Genetic factors conditioning resistance of Coffea arabica L. to Hemileia vastatrix Berk. et Br.. Agronomia Lusitana. 1971; 31: 285-292.
Bettencourt AJ, Rodrigues-Júnior CJ. Principles and practice of coffee breeding for resistance to rust and other diseases. In: Clarke RJ, Macrae R, editors. Coffee. London: Elsevier Applied Science; 1988. p. 199-234

Capucho AS, Zambolim L, Zambolim EM, Caixeta ET, Franchini E de A. Avaliação da resistência de cultivares de café à raça II de Hemileia vastatrix Berk. et Br. In: V Simpósio de Pesquisa dos Cafés do Brasil: Anais; 2007; Águas de Lindóia, Brazil. Águas de Lindóia: Consorcio Pesquisa Café; 2007. CDROM.

Carvalho CHS de, Fazuoli LC, Carvalho GR, Guerreiro-Filho O, Pereira AA, Almeida, SR de, et al. Cultivares de café arábica de porte baixo. In: Carvalho CHS de, editor. Cultivares de café: Origem, características e recomendações. Brasília: Embrapa Café; 2008. p. 157-224.

Cruz CD. Programa Genes: versão Windows; aplicativo computacional em genética e estatística. Viçosa: UFV; 2001.

Eskes AB. Resistance. In: Kushalappa AC, Eskes AB, editors. Coffee rust: epidemiology, resistance and management. Boca Raton: CRC Press; 1989. p. 171292.

Eskes AB, Carvalho A. Variation for incomplete resistance to Hemileia vastatrix in Coffea arabica. Euphytica. 1983; 32: 625-637.

Eskes AB, Costa WM. Characterization of incomplete resistance to Hemileia vastarix in the Icatu coffee population. Euphytica. 1983; 32: 649-657.

Eskes AB, Hoogstraten JGJ, Toma-Braghini M, Carvalho A. Race-specificity and inheritance of incomplete resistance coffee leaf rust in some Icatu coffee offspring and derivatives of Híbrido de Timor. Euphytica. 1990; 47: 11-19.

Matiello JB, Almeida SR, Carvalho CHS. Resistant cultivars to coffee leaf rust. In: Zambolim L, Zambolim EM, Várzea VMP, editors. Durable Resistance to Coffee Leaf Rust. Viçosa: UFV; 2005. p. 443-450.

Matiello JB, Santinato R, Garcia AWR, Almeida SR, Fernandes DR. Cultura de Café no Brasil - Novo manual de Recomendações. Rio de Janeiro e Varginha: MAPA/PROCAFÉ; 2005.

Matiello JB, Santinato R, Garcia AWR, Almeida SR, Fernandes DR. Cultura de Café no Brasil - Manual de Recomendações. Rio de Janeiro e Varginha: MAPA/PROCAFÉ; 2010.

Monaco LC, Carvalho A. Resistência a Hemileia vastatrix no melhoramento do cafeeiro. Cienc Cult. 1975; 27: 1070-1081.

Noronha-Wagner M, Bettencourt AJ. Genetic study of resistance of Coffea sp. to leaf rust. I. Identification and behaviour of four factors conditioning disease reaction in Coffea arabica to twelve physiologic races of Hemileia vastatrix. Can J Bot. 1967; 45: 2021-2031. 
Pereira AA, Carvalho GR, Moura WM, Botelho EC, Rezende JC, Oliveira ACB, et al. Cultivares: Origem e suas Características. In: Reis PR, Cunha RL, editors. Café arábica do plantio à colheita. Lavras: EPAMIG; 2010. p. 167-221.

Rodrigues-Júnior CJ, Bettencourt AJ, Rijo L. Races of the pathogen and resistance to coffee rust. Annu Rev Phytopathol. 1975; 13: 49-70

Rodrigues-Júnior CJ, Várzea VMP, Silva MC, GuerraGuimarães L, Rocheta M, Marques DV. Recent advances on coffee leaf rust. In: International Scientific Symposium on Coffee: Proceedings; 2000. Bangalore, India: Central Coffee Research Institute; 2000. p. 179-193.

Sera GH, Sera T, Fonseca IC de B, Ito DS. Resistência à ferrugem alaranjada em cultivares de café. Coffee Science. 2010a; 5: 59-66.

Sera GH, Sera T, Fonseca IC de B, Ito DS, Del Grossi L, Shigueoka LH, et al. Seleção para a resistência à ferrugem em progênies das cultivares de café IPR 99 e IPR 107. Bragantia. 2010b; 69: 547-554.

Sera GH, Sera T, Ito DS, Azevedo JA de, Mata JS da, Doi DS, et al. Resistance to leaf rust in coffee carrying $\mathrm{S}_{\mathrm{H}} 3$ gene and others $\mathrm{S}_{\mathrm{H}}$ genes. Brazilian Archives of Biology and Technology. 2007a; 50: 753757.

Sera GH, Sera T, Ito DS, Azevedo JA de, Mata JS da, Doi DS, et al. Selection for durable resistance to leaf rust using test-crosses on IAPAR-59 and Tupi IAC 1669-33 cultivars of Coffea arabica. Brazilian Archives of Biology and Technology. 2007b; 50: 565570.
Várzea VMP, Marques DV. Population variability of Hemileia vastatrix vs. coffee durable resistance. In: Zambolim L, Zambolim EM, Várzea VMP, editors. Durable Resistance to Coffee Leaf Rust. Viçosa: UFV; 2005. p. 53-74.

Várzea VMP, Rodrigues-Júnior CJ, Silva MCML, Gouveia M, Marques DV, Guerra-Guimarães L, et al. Resistência do cafeeiro a Hemileia vastatrix. In: Zambolim L, editor. O Estado da arte de tecnologias na produção de café. Viçosa: UFV; 2002. p. 297-320.

Waller JR, Bigger M, Hilocks RJ. Foliage and shoot diseases. In: Waller JR, Bigger M, Hilocks RJ, editors. Coffee pests, diseases and their management. Wallingford: CABI; 2008. p. 171-210.

Zambolim L, Vale FXR, Pereira AA, Chaves GM. Manejo integrado das doenças do cafeeiro. In: Zambolim L, editor. In: I Encontro sobre Produção de Café com Qualidade. Viçosa: Editora UFV; 1999. p.134-215.

Zambolim L, Zambolim EM, Vale FXR do, Pereira AA, Sakiyama NS, Caixeta ET. Physiological races of Hemileia vastatrix Berk. et Br. in Brazil Physiological variability, current situation and future prospects. In: Zambolim L, Zambolim EM, Várzea VMP, editors. Durable Resistance to Coffee Leaf Rust. Viçosa: UFV; 2005. p. 75-98.

Received: May 16, 2011; Revised: March 20, 2012; Accepted: June 28, 2012. 